\title{
Creating Shared Value in BoP Communities with Micro-Manufacturing Factories: A Systematized Literature Review
}

\author{
Zviemurwi J. Chihambakwe ${ }^{1,{ }^{*}}$, Sara S. Grobbelaar ${ }^{1,2}$, Stephen Matope ${ }^{1}$ \\ ${ }^{1}$ Department of Industrial Engineering, Stellenbosch University, P Bag X1 Matieland, \\ Stellenbosch 7602, South Africa \\ ${ }^{2}$ DSI-NRF CoE in Scientometrics and Science, Technology and Innovation Policy, \\ Stellenbosch University, South Africa \\ ${ }^{*}$ zviemurwi.chihambakwe@gmail.com
}

\begin{abstract}
Background: Shared value creation in Base of the Pyramid (BoP) communities is a crucial process towards building sustainable societies. BoP communities in developing countries represent more than four billion people who live on low incomes with limited access to basic products and services. Current or emerging technologies offer promising solutions for organisations pursuing manufacturing opportunities in BoP communities.

This study seeks to explore the literature on how BoP communities may become active participants in sustainably manufacturing products using micro-manufacturing factories. The research question posed is: What are the core concepts that need to be taken into consideration for creating shared value through micro-manufacturing factories in BoP communities?

Method: A Systematised Literature review (SLR) was completed following the Preferred Reporting Items for Systematic reviews and Meta-Analysis (PRISMA) method for data selection criteria and analysis. The SLR is used to explore the state of literature with regards to creating manufacturing shared value in BoP communities with the objective to identify study gaps and to explore shared value creation concepts.

Results: Literature indicates $\mathrm{BoP}$ initiatives that have pursued to engage $\mathrm{BoP}$ communities through various innovation strategies. The findings of the review is organised under three strategic pillars: Capability building strategy, Implementation process, and Growth strategy. The capability building strategy defines the users' intention to create shared value in BoP communities with Micro-manufacturing factories (MMF). It is followed by the implementation process which guides the users to create manufacturing shared value in BoP communities. This is followed by a growth strategy to scale for impact.
\end{abstract}

Keywords. Systematized Literature Review, Base of the Pyramid, Shared Value creation, Micro-manufacturing factories, Business model 


\section{Introduction}

BoP communities constitute a group of people who are generally marginalized and have limited access to technologies that can enhance their lives. The concept of the BoP was first introduced by Prahalad and Hart at the turn of the $21^{\text {st }}$ century. Prahalad (2009) defined the BoP as the world's 4 billion poor people who live on less than USD $\$ 2$ per day (Prahalad, 2009). A more recent definition is that the BoP represents a socio-economic segment that has a potentially enormous and relatively untapped market (London, 2020).

Strategies to include the BoP have moved from BoP 1.0 which proposed selling products and providing services to the poor towards a bottom-up approach of co-creation (BoP 2.0) (Arora and Romijn, 2012: Simanis and Hart, 2008). The co-creation process moves beyond just mere inclusion to cross sector partnerships that work together to provide the best innovation products in BoP communities termed BoP 3.0 (Cañeque and Hart, 2015; Van Der Merwe et al., 2018).

Creating shared value (CSV) was popularised by Porter and Kramer in the context of a company (Porter and Kramer, 2011). They defined CSV as the policies and operating practices that can enhance the competitiveness of a company whilst advancing the economic and social conditions in the communities they operate in. Through shared value the needs and challenges faced by a society are met in the process of creating economic value (Porter et al., 2011). The idea as approached in this article is for an organization to identify opportunities usually presented as problems in BoP communities and then solve them through innovation, often through the use of technology. Through this process current or emerging technologies are used to provide products and services in a way that creates value for the BoP community.

This article explores the extant literature dealing with manufacturing in $\mathrm{BoP}$ communities with a focus on micro-manufacturing factories which can be defined as not capital intensive and employing less than twenty people. The choice for exploring manufacturing services in $\mathrm{BoP}$ communities is based on a proposition that most economies rely on the manufacturing industry to drive economic development (Ueda et al., 2009). Manufacturing is a driving force of economic growth, job creation and poverty reduction in developing countries as well as a means to accelerate rapid industrialization (Okpara and Wynn, 2007).

Micro-manufacturing is a process where manufacturing of small quantities of a product is done in small manufacturing facilities (Slepov, 2016) ${ }^{1}$. Micro-manufacturing factories can be implemented using modular factories that comprise of several prefabricated volumetric elements to be assembled to make one factory or container based factories (Fox, 2015; Madyira, 2016; Chihambakwe et al., 2019). Implementation of

1 Micromanufacturing the future https://techcrunch.com/2016/04/03/micromanufacturing-thefuture/ 
micro-manufacturing factories can be seen as instrumental in overcoming the lack of infrastructure often encountered in BoP communities. These factories utilize locally sourced raw materials and human labor and utilize sustainable manufacturing processes (Fox, 2015). The products and processes are designed and operated considering the entire supply chain to ensure sustainability.

This study seeks to understand the process of creating shared value in BoP communities with micro-manufacturing factories. The aim of this study is to explore current literature regarding how shared value can be created in BoP communities with micromanufacturing factories. The research question for this study which will be explored using a systematized literature review is as follows:

"What are the core concepts that need to be taken into consideration for creating shared value with micro-manufacturing factories in communities at the BoP?"

The methodology for conducting the systematized literature review (SLR) is discussed in section 2 of this article. Section 3 present the descriptive and content analysis of the SLR with the conclusions in section 4 and future work and study limitations in section 5 .

\section{$2 \quad$ Methods}

This study follows a structured Systematized Literature Review (SLR) approach. The approach helps to ensure a systematic and replicable study that draws conclusions in literature (Grant and Booth, 2009). The Preferred Reporting Items for Systematic reviews and Meta-Analysis (PRISMA) approach was adopted for data selection criteria and analysis (Moher et al., 2009; Rethlefsen et al., 2021). The research process can be mapped out through the following steps: Step 1: Identifying relevant articles for the study; Step 2: Study selection criteria; Step 3: Categorizing the data and Step 4: Analyzing, summarizing, and reporting - these are described in the sections to follow.

\subsection{Step 1: Identifying relevant articles for the study.}

The databases selected for review were Google Scholar, Web of Science core collection, Scopus and Science Direct (Rethlefsen et al., 2021). Various combinations of the following search terms were used for each database, "Shared value creation", "Base of the pyramid", "Base of the pyramid communities", "micro container factories", "micro-manufacturing factories" "small manufacturing factories" and "innovation" to form search strings. The search strings were combined as shown in Error! Reference source not found. 
Table 1. Search Strings and Search Results

\begin{tabular}{|c|c|c|c|c|c|}
\hline Keywords & Search Strings & $\begin{array}{l}\text { Science } \\
\text { Direct } \\
\text { Results }\end{array}$ & $\begin{array}{l}\text { Scopus } \\
\text { Results }\end{array}$ & $\begin{array}{l}\text { Web of } \\
\text { science } \\
\text { Results }\end{array}$ & $\begin{array}{l}\text { Google } \\
\text { scholar } \\
\text { Results }\end{array}$ \\
\hline $\begin{array}{l}\text { Shared value creation, } \\
\text { base of the pyramid }\end{array}$ & $\begin{array}{l}\text { "Shared value creation" AND } \\
\text { "base of the pyramid" }\end{array}$ & 7 & 3 & 7 & 251 \\
\hline $\begin{array}{l}\text { Shared value creation, } \\
\text { factories }\end{array}$ & $\begin{array}{l}\text { "Shared value creation" AND } \\
\text { "factories" }\end{array}$ & 12 & 9 & 11 & 314 \\
\hline $\begin{array}{l}\text { Base of the pyramid, } \\
\text { manufacturing factories }\end{array}$ & $\begin{array}{l}\text { "Base of the pyramid" AND } \\
\text { "manufacturing factories" }\end{array}$ & 1 & 1 & 7 & 10 \\
\hline $\begin{array}{l}\text { Base of the pyramid, } \\
\text { factories }\end{array}$ & $\begin{array}{l}\text { "Base of the pyramid" AND } \\
\text { "factories" }\end{array}$ & 168 & 6 & 12 & 2250 \\
\hline $\begin{array}{l}\text { Base of the pyramid, } \\
\text { container factories }\end{array}$ & $\begin{array}{l}\text { "Base of the pyramid" AND } \\
\text { "container factories" }\end{array}$ & 0 & 0 & 0 & 1 \\
\hline $\begin{array}{l}\text { Shared value creation, } \\
\text { base of the pyramid, } \\
\text { factories }\end{array}$ & $\begin{array}{l}\text { "Shared value creation" AND } \\
\text { "base of the pyramid" AND } \\
\text { "factories" }\end{array}$ & 3 & 1 & 1 & 50 \\
\hline $\begin{array}{l}\text { Innovation, base of the } \\
\text { pyramid, factories }\end{array}$ & $\begin{array}{l}\text { "Innovation" AND "base of } \\
\text { the pyramid" AND "factories" }\end{array}$ & 85 & 0 & 0 & 1490 \\
\hline TOTAL & & 276 & 20 & 38 & 4366 \\
\hline
\end{tabular}

\subsection{Step 2: Study selection criteria}

The initial search process was conducted in December 2019 and then updated on 26 February 2021. Records were documented on excel sheets for selected articles as well as those eliminated after the first screening process until only screened articles remained. The screening process resulted in 62 articles that were analysed to extract relevant concepts that answer the study research question, see Error! Reference source not found. 


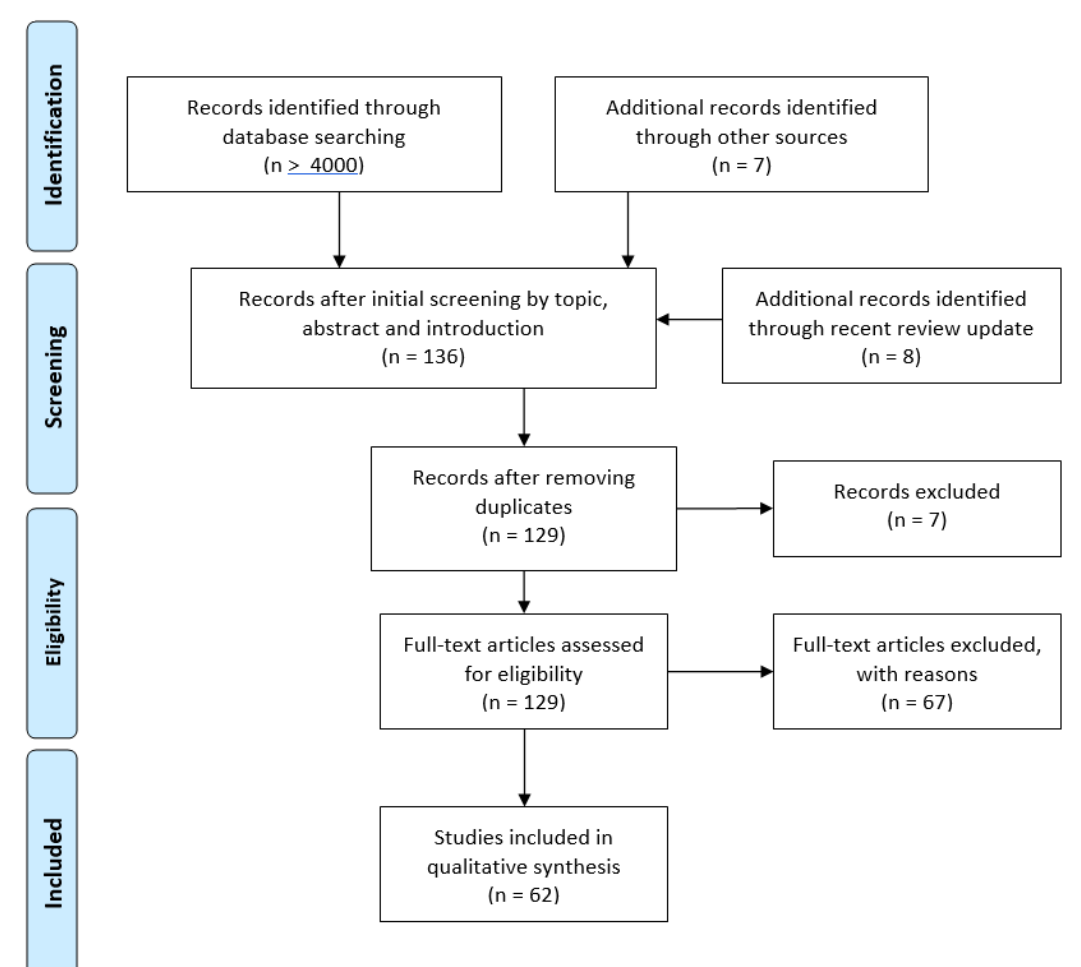

Fig. 1. Systematized review data selection adopted from PRISMA (Moher et al., 2009)

\subsection{Step 3: Categorizing the data.}

The review was used to extract different kinds of information in the following three categories: i) conceptual aspects, ii) empirical aspects and iii) significance and conclusions. The conceptual aspects category gives information that establishes the type of document analyzed, where the research was conducted and author analysis. The empirical aspects category analyzed the documents to extract information which includes the gap in literature addressed, how it was addressed, and the validation approaches used. The review process identified the significance of the document and the conclusions that were drawn from the document as well as recommendations for future studies.

\subsection{Step 4: Analyzing, summarizing, and reporting.}

The findings from the SLR are discussed in section 4. The analysis gives the descriptive statistics of the review as well as the content analysis from the findings. In section 3.3 a synthesis is presented from the key concepts as identified in the review - this then forms the basis of the conceptual review presented in the conclusion in section 4 . 


\section{$3 \quad$ Findings}

The following section presents the descriptive statistics of the literature review and the content analysis. It also summarizes the key concepts for creating manufacturing shared value in BoP communities.

\subsection{Descriptive statistics}

\subsubsection{Type of publication and citation}

The publishers of selected articles were from various disciplines showing that this study is multidisciplinaryError! Reference source not found.. A total of 59 reviews were published in the last decade which is not surprising as the BoP concept became more prominent in the last decade. Also, the literature database for this study is mostly made up of journal articles as can be seen in Error! Reference source not found. \& Error! Reference source not found.. The highest citations on articles were from Porter and Kramer (2011) who popularised the CSV concept and Prahalad (2002) who introduced the BoP concept.

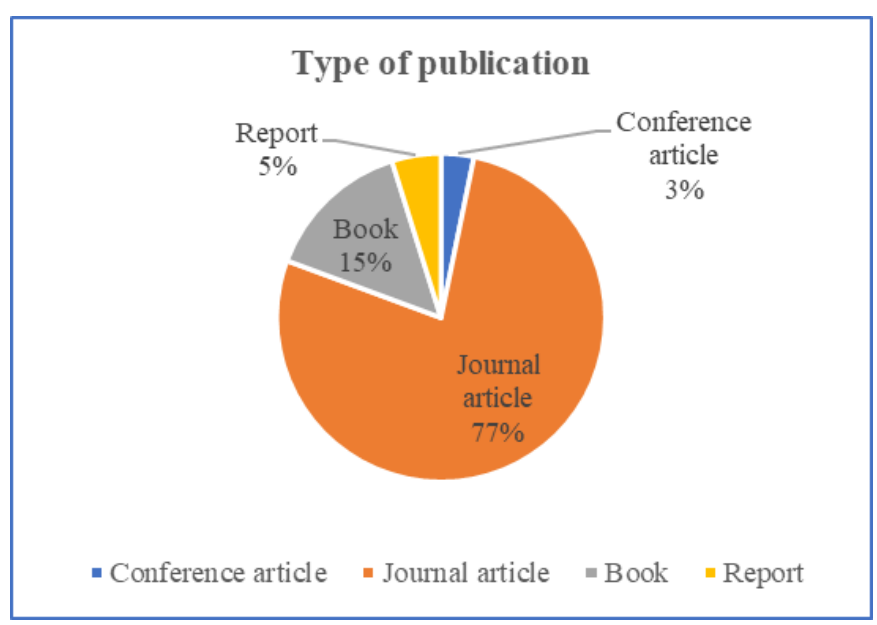

Fig. 2. Type of publication 


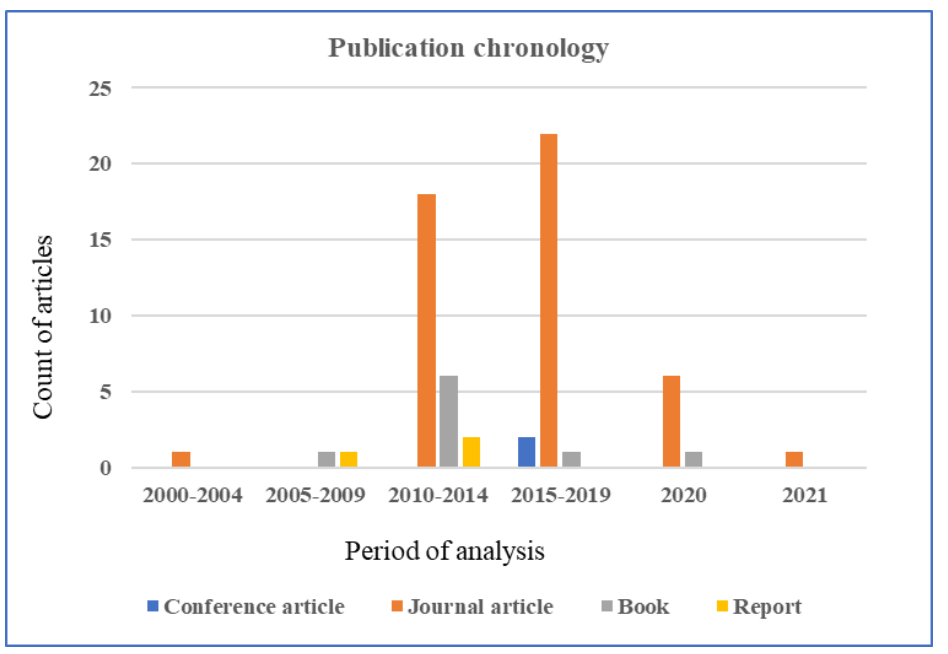

Fig. 3. Publication chronology

\subsubsection{Geographical location of authors}

There has been an interest in the past decade by authors mostly from developed countries to study how livelihoods can be improved in BoP communities of developing countries.

The articles selected in our sample show that the USA had the most significant number of authors publishing the articles (see Fig. 4). It is important to note that the studies in our sample have been written mostly by authors from developed countries except for India where the $\mathrm{BoP}$ concept originated. This may be indicative of a gap in this regard where research in the study area seems to be poorly developed, especially in Africa. More insights can be gained from researchers as they explore the various initiatives that have been done or are being done on manufacturing shared value creation in BoP communities. Studies have been done on how sustainable business models can be used to create shared value in BoP communities. These business models emphasize the need to co-create products and services in the BoP communities. The process involves employing frugal innovations ${ }^{2}$ that use emerging or current technologies to solve problems in these communities.

${ }^{2}$ Frugal innovation is defined as methods and designs applied for low-cost new products, that have been created for or come out of the BoP (https://www.oxford-review.com/oxford-review-encyclopaedia-terms/frugal-innovation/) 


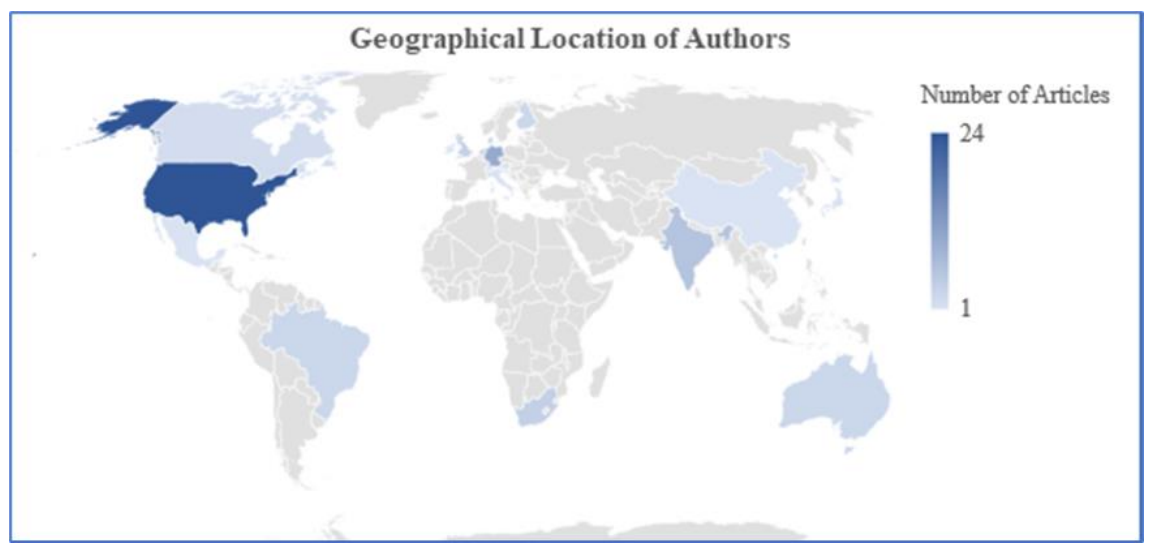

Fig. 4. Geographic location of authors

\subsubsection{Geographic focus areas of the studies}

Most of the articles reviewed were not specifically conducted for any BoP geographical location (see Fig. 5). Our study sample shows that case studies were done of companies which pursued opportunities in BoP communities in Asia. For those who conducted case studies, they were mostly done in line with the author trends. It is noted that the studies have little coverage of the African context. This indicates an opportunity for future work to focus on case studies in Southern Africa with an intent of adding to the body of knowledge on how manufacturing shared value can be created in BoP communities.

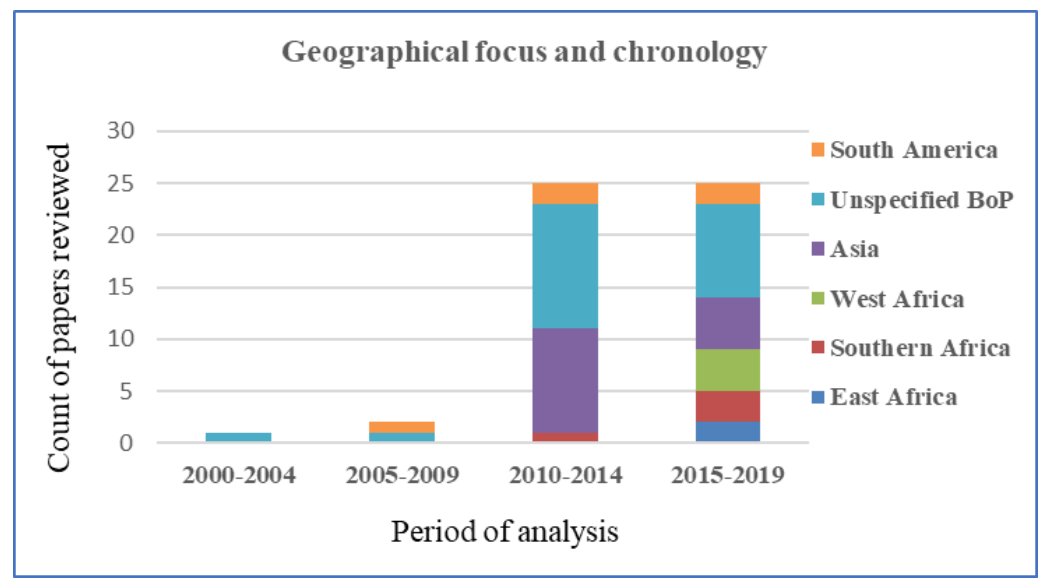

Fig. 5. Geographic focus of research case studies and chronology 


\subsection{Content analysis}

Content analysis helps collate and synthesise information to derive valid insights (Krippendorff, 2004). In this section the articles in our sample are analysed considering issues related to creating manufacturing shared value in BoP communities.

\subsubsection{Value creation in BoP communities}

BoP communities present various opportunities for value creation. They can be grouped into segments based on their level of income (Kasturi Rangan et al., 2011). It is hence insightful to map out which value creation strategies work best for each specific segment of the BoP. Literature suggests that value creation in BoP communities must offer affordable, user-friendly and environmentally sustainable products (Panapanaan et al., 2016 ; Desa and Koch, 2014). Local empowerment through the use of local resources and capability building is acknowledge as important (Albert et al., 2014). This can assist in eliminating issues of poverty and violent conflict that impede growth (Tashman and Marano, 2010).

In order to contextualise our analysis of value creation approaches, it is necessary to revisit the evolution of the field from BoP 1.0 to BoP 3.0. The BoP 1.0 strategy was about selling basic products and services to the BoP i.e., treating the BoP as a market (Prahalad and Hammond, 2002). This strategy mostly benefited BoP ventures but is widely seen to have lacked the empowerment and inclusion of BoP communities. Critics argue that this can lead to the poor being exploited and seen as purely a market (Karnani, 2007).

This led to a shift towards the BoP 2.0 strategy which incorporated community members in value chains through co-creation (Simanis et al., 2008). However, this has been seen not to be enough with the current move towards BoP 3.0 strategies that create winwin relationships through long term investments and focus on innovation ecosystems embedded in the BoP communities (Filard et al., 2018; Cañeque and Hart, 2015; Dembek et al., 2019).

Results from the review in Error! Reference source not found. echo the transition of BoP 1.0 to BoP 3.0 and shows that value creation in BoP communities has gained more interest in the last decade. Studies focussed increasingly on co-creation of products or services between 2012 and 2015 (in line with the BoP 2.0 approach by Simanis and Hart (2008). Studies on business model approaches for BoP value creation have shown growth in the last two decades. The shift in the last five years mainly focuses on the sustainable business model approach and shared value creation which is indicative of the move towards the BoP 3.0 strategy. 


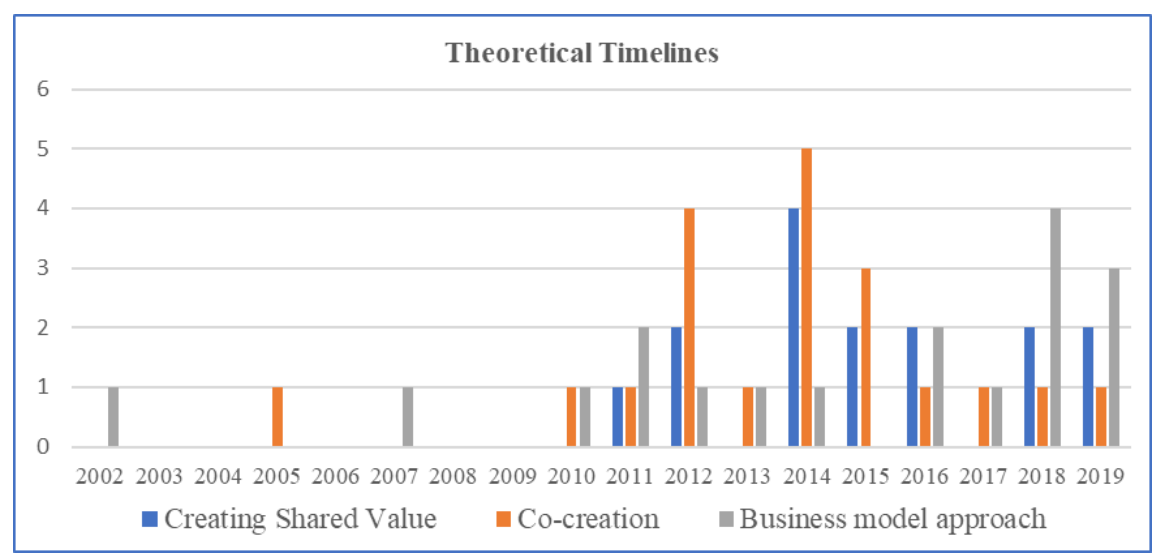

Fig. 6. Theoretical Timelines for value creation in BoP communities

\subsubsection{Pillars for creating shared value in BoP communities and how they are executed in literature}

The concept of Creating Shared Value (CSV) as conceptualized by Porter and Kramer focusses on three key pillars i.e. Key pillar 1: Reimagining products and markets, Key pillar 2: Redefining productivity in the value chain and Key pillar 3: Enabling local cluster development (Porter et al., 2011). These key pillars address fundamental concepts that are required to create manufacturing shared value in BoP communities.

The first pillar shows how companies can come up with innovative and sustainable business models that identify and address opportunities for manufacturing shared value in BoP communities (Hossain, 2021; Varadarajan and Kaul, 2018). The second pillar puts emphasis on defining the processes required to address these opportunities in BoP communities taking into consideration efficiency in entire value chains (Panapanaan $e t$ al., 2016; Spitzeck and Chapman, 2012). The third pillar then addresses scaling strategies that address sustainability issues necessary for social and economic impact (Desa et al., 2014).

Most of the articles reviewed did not address all three the key pillars for CSV especially the pillar on enabling local cluster development (see Error! Reference source not found.). It was noted that most ventures studied only focused on reimagining products and services for the BoP communities. This shows the need for further research to demonstrate how all the three key pillars of CSV can be applied in BoP communities. 


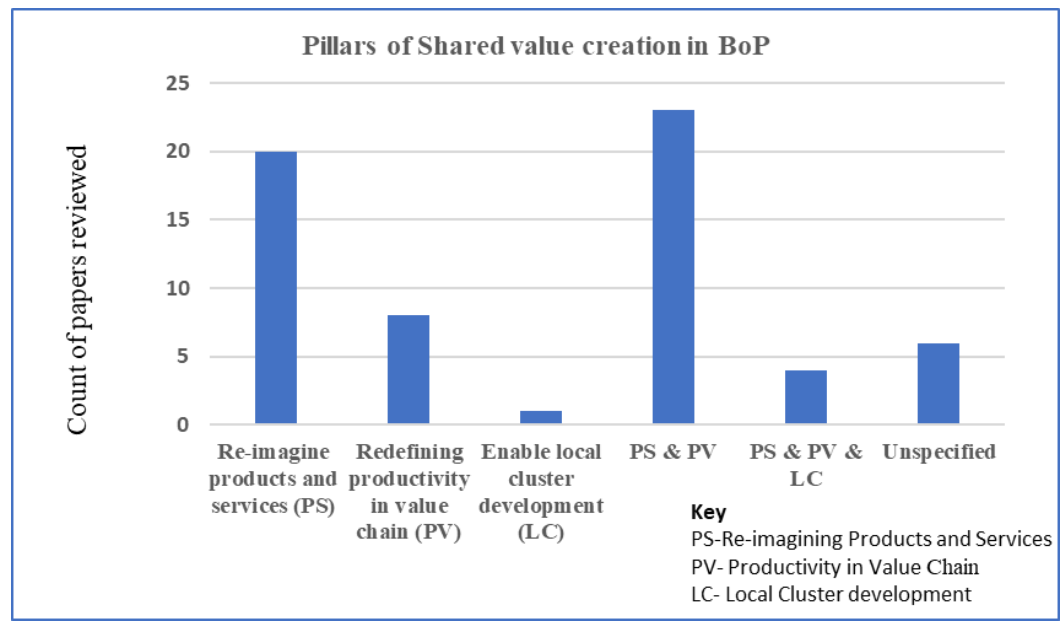

Fig. 7. Pillars of CSV in BoP

\subsubsection{Innovation in BoP communities}

The articles reviewed in our sample were analyzed to explore innovation pursued in BoP communities. Most articles reviewed included BoP innovation with a focus on products as well as technology transfer. Technology transfer to the BoP is seemingly more attractive and has better payoffs compared to product innovation.

The literature explores how that BoP communities can benefit from innovations that offer affordable products and technology transfer which adds value and improve livelihoods (Prahalad, 2005; Panapanaan et al., 2016). Technology is here acknowledged to often drive innovation in BoP communities (Leke et al., 2018). Breakthrough product innovations also develop ecosystems that enable an environment where businesses thrive (Prahalad, 2012).

Product designs are mostly focused on employing frugal innovations which use modular and scalable designs with flexible production systems (Arnold, 2018; Chopra and Narayana, 2012). It is also widely acknowledged that it is necessary to get embedded and more acquainted with the BoP way of life for inspiration to design innovative products or services for BoP communities (Lashitew et al., 2018). Becoming embedded in the BoP community will also build trust and demand in the BoP communities for the products and technologies to be adopted.

Innovations that address local waste streams and environmental issues are key to succeed in creating manufacturing shared value in BoP communities (Brix-asala et al., 2016; Plambeck and Ramdas, 2020).

Lack of start-up capital to ensure the successful implementation of product innovations can be overcome by having initial capital costs of some innovations covered by 
grants or subsidies and then developing effective means to grow profitably (Knuckles, 2016). This approach allows the realization of the product innovation as most BoP community developments are impeded by lack of start-up capital.

\subsubsection{BoP supply chains}

The sample reviewed highlighted the need for inclusive and effective supply chain networks in BoP communities. To achieve shared value creation in BoP communities, the supply chains must involve community members. It should be noted that the route to market for BoP suppliers who are in the informal market is considered as a risk and requires trust to thrive (Holt and Littlewood, 2014). This impediment can be improved if the BoP suppliers acquire unique skills and resources that allow them to operate with profitable business models which are more acceptable in formal markets (Holt et al., 2014).

In many cases BoP suppliers find themselves earning very little from their products because they do not have access to markets. This has been addressed by creating supply chain networks that protect them from middlemen. This is achieved by formation of cooperatives, working alongside political unionization for strong influence in supply chains and creating social networks that expand beyond local communities (Prasad et al., 2017).

Strategies for sales effectiveness, product distribution and awareness campaigns should be considered to counter the negative impacts on sales whenever there is a price change (Reiner et al., 2015). This is done because BoP customers are sensitive to price changes. Designing BoP supply chains with long-term relationships and capacity building is a key to success (Gold et al., 2013).

\subsubsection{Creating manufacturing value in BoP communities}

In our sample of literature, it has come to light that there is a need to create manufacturing shared value in BoP communities. The literature analysis revealed that only 54 articles could be found which focus on manufacturing factories in $\mathrm{BoP}$ communities.

The process of micro-manufacturing factories at the BOP requires frugal innovations (Arnold, 2018) in order for manufacturing systems to meet the requirements of pricesensitive customers, yet still be of good quality (Schleinkofer et al., 2019; Varadarajan et al., 2018). Various design considerations are thus to be considered for micro-manufacturing factories in BoP communities (Rodrigues and Baker, 2012): (Biswas et al., 2014).

As micro-manufacturing is a process where small quantities of a product are produced at a time in a small factory (Slepov, 2016), proposals have been made for microcontainerised factories which provide portable, scalable technologies to produce valuable products from sustainable locally sourced resources or waste streams (Chihambakwe et al., 2019). They can also be designed as moveable factories that cover 
various places in BoP communities and have capacity to carry their own power generation (Fox, 2015).

Implementing CSV principles allows BoP communities to learn organizational and business management skills as they participate in supply chains. The result being a community with members who are self-dependent. The goal for CSV is to serve customers profitably and, look after the BoP communities (Nittapaipapon and Atchattabhan, 2016). Micro-manufacturing factories toned to manage productivity constraints that affect their operations (London et al., 2010). Manufacturing in BoP communities thus requires the ability to adapt production techniques and to co-create products with locals (Jacob and Pin, 2011). The final factory location decision also depends on the individual company, its strategy, its preferences, and its circumstances (Moellmann and Thomas, 2019).

\subsubsection{Various stakeholders and partnerships involved in BoP initiatives}

Our study sample gave insight into the various stakeholders and partnerships that are required when operating in BoP communities. Involving strategic partners and stakeholders from the beginning is seen as important. Every partner is crucial and hence their inclusion has to be carefully considered (Hahn and Gold, 2014).

These partnerships allow companies to gain credibility or legitimacy as they operate in BoP communities (Schuster and Holtbrügge, 2014). Various role players contribute to make partnerships stronger. Cross-sectoral partnerships (government, business and civil society) are required to create employment opportunities, increase employability as well as make the labour market more efficient (Karnani, 2011). In these partnerships roles may exist for companies to identify opportunities and provide financial capability, NGOs can integrate and connect the companies with the local people (Arnold, 2018). NGOs and other intermediary organizations can provide access to knowledge and strengthen skills building through training and coaching, facilitate access to information and finance, and build networks (Varga and Rosca, 2019). The role of civil society is often to advocate on behalf of the BoP to ensure that they have jobs and all capabilities they require to become employable.

Cross-sector partnerships assist to become more responsiveness to market conditions and customer needs as well as the environmental requirements in the BoP communities (Schuster et al., 2014). These partnerships need to be leveraged to ensure local communities are included in the manufacture, supply chains and distribution of products (Panapanaan et al., 2016).

Finding common ground for all parties is necessary to the success of partnerships. BoP incubators and BoP knowledge centers have in the past proven to provide a pool of valuable information that can assist BoP ventures with minimal critical specifications for capability building (Desa et al., 2014). These knowledge centers can be used to train students from local universities to design innovative products and services for the BoP. 
They can also be used for training youths in the local community vocational skills so that they can be employable in the micro-manufacturing factories.

Synergies between the various actors in BoP ventures require careful identification of the most appropriate partners and then further developing personal relationships, communication routines, common goals and vision, long-term commitment, and partner-specific capacity building (Hahn et al., 2014). Inclusive innovation through human capital development and capability building is fundamental to growth and value creation in BoP communities (Peerally et al., 2019). It is also necessary to create partnerships between companies operating in BoP communities and consultancy firms that assist in measurement of metrics to evaluate their impact in BoP communities (Spitzeck et al., 2012a). Performance measurement is always important so that you can pause and reflect on progress made and then rectify where it is necessary to adjust. Partnerships involving all these stakeholders if possible are key to successful BoP ventures.

\subsubsection{BoP frameworks and business models for creating shared value}

The literature reviewed emphasised the need for companies to develop business models that are specific for the BoP (Hossain, 2021). This enable actionable approaches for knowledge sharing, learning, creating mutual value, and building ecosystems (London et al., 2014). Focus is to be on approaches that take into consideration the widely acknowledged 4 A's framework: acceptability, affordability, awareness and availability of products (Angeli and Jaiswal, 2015). Ensuring sustainability as a factor in the business model is important and can be built through support from the government which provide legitimacy, attractive regulations and partnerships that help to reduce costs (Marconatto et al., 2016; Dembek and York, 2020; Hossain, 2021).

A manufacturing factory should use business models and frameworks that overcome socio-cultural, religious, infrastructural, and structural challenges (Biswas et al., 2014). It was noted that having a manufacturing factory near raw materials and supply chain networks will help to reduce costs and is more practical (Rodrigues et al., 2012).

Adopting inclusive business models to expand economic opportunities is necessary to build local enterprises that can be scaled for impact (Jenkins, 2007; Gaertner and Ishikawa, 2014). There is a need for business models with innovations that are easily replicable, and have easy market penetration for scaling to other geographical locations (Desa et al., 2014). Market based business oriented models provide win-win scenarios for the poor by covering part of their costs (Goldsmith, 2011; Prahalad, 2005). This business model approach tends to be more effective because an entrepreneur or individual contributes towards initial investments which instils a sense of ownership in them.

The business models should be evaluated to ensure that they are sustainable and replicable in the long term for scaling (Knuckles, 2016). Evaluation requires frameworks that offer variables for measuring affordability, profitability, and sustainability (Panapanaan et al., 2016; Spitzeck et al., 2012). 


\subsubsection{Validation approaches for BoP models and frameworks}

Literature reviewed revealed that that there are various means of validating business model approaches and proposed frameworks. It was interesting to note that most approaches were validated using case studies where expert opinion is sought and then triangulating data with other sources to ensure validity.

If research will have practical impact, it is necessary for one to show that the approach you are proposing has been tested and validated. Frameworks and business models can be validated by conducting case studies of previous BoP ventures to evaluate where their strategies succeeded or failed. Here it is important to develop sound metrics for evaluating measurable impact (Varga et al., 2019). Metrics that measure the economic, social and environmental impact of creating manufacturing shared value in BoP communities are used to highlight key performance indicators. The evaluation process reveals whether there is shared value creation and if there is a need to change the business model approach.

\subsubsection{Implementing micro-manufacturing factories in BoP communities as so- cial enterprises}

The study has shown an inclination in the literature towards the implementation of micro-manufacturing factories as social enterprises. Social enterprises can be defined as for-profit, social-purpose investments and organizations whose goal is economic betterment of deprived groups (Goldsmith, 2011). Through social purpose business ventures stable economic opportunities for the BoP community may be achieved (Rahdari et al., 2016; Jäger et al., 2020).

Social enterprises can create opportunities for BoP community members and ensure their well-being which may not be addressed by the government and private sector (Carlson and Koch, 2017; Armstong and Grobbelaar, 2018). They attain social bricolage by ensuring continuous innovation, improvising constrained resources and empowering the disadvantaged for inclusive growth (Azmat et al., 2015). A social enterprise can leverage on its impact to source funding to scale (Jäger et al., 2020).

Social enterprises are usually managed by social entrepreneurs using a bottom up approach with support of resources from companies (Carlson et al., 2017). Selection of social entrepreneurs are to be based on certain attributes including a strong emotional attachment to the BoP communities (Siebold et al., 2019).

\subsubsection{Balancing social, economic, and environmental value creation in BoP communities}

Creating shared value connects the economic success of an organization with the BoP community's improvement. The improvement in the BoP community is based on the social and environmental impact of the organization's activities. From this study, it can be concluded that the ability to balance social, economic, and environmental value 
creation is of importance when pursuing manufacturing shared value in BoP communities.

Social product innovations are capable of solving social problems in BoP communities resulting in a win-win situation (Varadarajan et al., 2018). Social value creation entails building human capabilities, socio-economic equity, and self-respect. It ensures a good source of sustenance and builds self-confidence as well as freedom of choice (Sinkovics et al., 2014). This brings about well-being which can be interpreted as pleasure, desire-fulfilment, or freedom of choice (Ansari et al., 2012). There is favorable bias from BoP community members to support those investing in their community if they are seen to be consciously preserving their environment (Spitzeck and Chapman, 2012b).

\subsection{Key concepts for BoP manufacturing shared value creation towards a conceptual framework}

Keys concepts for creating manufacturing shared value in BoP communities from the previous sections were identified from the reviewed literature. The identified concepts are used to develop a conceptual framework for future work.

The conceptual framework is based on the three key pillars of CSV adopted from Porter and Kramer (2011). These key pillars will be classified into Manufacturing Shared Value (MSV) strategies namely; Capability building strategy, Implementation process, and Growth strategy. The capability building strategy defines the users' intention to create shared value in BoP communities with Micro-manufacturing factories (MMF). It is followed by the implementation process which guides the users to create manufacturing shared value in BoP communities. This will be followed by a growth strategy to scale for impact.

Each of the key aspects involved in executing all the MSV strategies is described and followed up with questions to be addressed by the users (see Table 2.) 


\begin{tabular}{|c|c|c|c|c|}
\hline & & & & $\begin{array}{l}\text { - Are the production processes simple? } \\
\text { - What are the energy and water requirements for the production processes? } \\
\text { How can these be minimised? } \\
\text { - Is there any need for waste management? }\end{array}$ \\
\hline & & $\begin{array}{l}\text { - Environmen- } \\
\text { tal conserva- } \\
\text { tion }\end{array}$ & $\begin{array}{l}\text { Waste management and } \\
\text { mitigation processes }\end{array}$ & $\begin{array}{l}\text { - Is there any waste from the production processes? } \\
\text { - Does the product packaging cause any environmental damage? } \\
\text { - Which environmental mitigation process can be implemented? }\end{array}$ \\
\hline & & $\begin{array}{l}\text { Monitoring } \\
\text { and evalua- } \\
\text { tion }\end{array}$ & $\begin{array}{l}\text { Measurement of key per- } \\
\text { formance indicators }\end{array}$ & $\begin{array}{l}\text { - Which metrics of evaluation are to be used? } \\
\text { - How will the metrics of evaluation be measured? } \\
\text { - How often does M\&E need to be done? }\end{array}$ \\
\hline \multirow{3}{*}{ 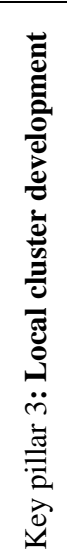 } & \multirow{3}{*}{ 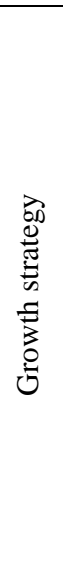 } & - $\quad$ Scaling & $\begin{array}{l}\text { Implementing more MMF } \\
\text { to meet increasing product } \\
\text { demand in current or new } \\
\text { BoP markets }\end{array}$ & $\begin{array}{l}\text { Is the current MMF fully operational and profitable? } \\
\text { - Are there resources for implementing other MMF factories? } \\
\text { - How will the scaling process be done? Should the same products be produced } \\
\text { in the same community or a different product using the same model? } \\
\text { Are there other similar BoP communities where the same business model can } \\
\text { be implemented? }\end{array}$ \\
\hline & & $\begin{array}{l}\text { - Cluster Ca- } \\
\text { pability } \\
\text { building }\end{array}$ & $\begin{array}{l}\text { - Empowering surrounding } \\
\text { supporting business } \\
\text { - Improving BoP commu- } \\
\text { nity livelihoods }\end{array}$ & $\begin{array}{l}\text { - Which surrounding businesses are key to the MMF operations? } \\
\text { - How can the company support other surrounding businesses to build their } \\
\text { cluster network? }\end{array}$ \\
\hline & & $\begin{array}{ll}\text { - Sustainabil- } \\
\text { ity }\end{array}$ & $\begin{array}{l}\text { Ensuring that all company } \\
\text { activities have economic } \\
\text { and social impact and are } \\
\text { environmentally friendly }\end{array}$ & $\begin{array}{l}\text { - Is the MMF profitable? } \\
\text { - Is the MMF creating shared value in the community? } \\
\text { - Are the operations environmentally safe? }\end{array}$ \\
\hline
\end{tabular}

How can these be minimised?

there any waste from the prod

Des the product packaging cause any environ

- Which metrics of evaluation are to be used?

- How will the metrics of evaluation be measured?

- How will the scaling process be done? Should the same products be produced

be implemented?

- How can the company support other surrounding businesses to build their

Improving BoP commu-

Ensuring that all company environmentally friendly

- Is the MMF creating shared value in the community?

Are the operations environmentally safe? 


\section{Conclusion}

The study recognized the potential for pursuing manufacturing shared value in BoP communities. The road towards this achievement has various challenges and limitations. However, the fulfillment surpasses the challenges faced. The beauty of it all being that it is a mutual fulfilment where shared value is created.

The study identified concepts that are key to creating shared value in BoP communities through micro-manufacturing factories. These concepts were used to develop a conceptual framework illustrated in Fig. 8.

In conclusion creating manufacturing shared value in BoP communities with micromanufacturing factories is an important study. It provides a means for those seeking to do well by doing good to grow whilst communities they operate in grow with them. It was noted that many solutions have been offered to BoP communities but there is still a gap in literature on how manufacturing shared value can be created with micro-manufacturing factories in Southern Africa. There has been interest by researchers in the past decade to explore growth strategies in BoP communities using innovative solutions for social problems. Literature reveals great strides and milestones towards this. However, pursuing these underprivileged communities has many hurdles. It requires determination and a desire to see livelihoods improved at the expense of short-term profitability. From this review, providing technologically innovative solutions in BoP communities works for those who do so with a long-term focus. 


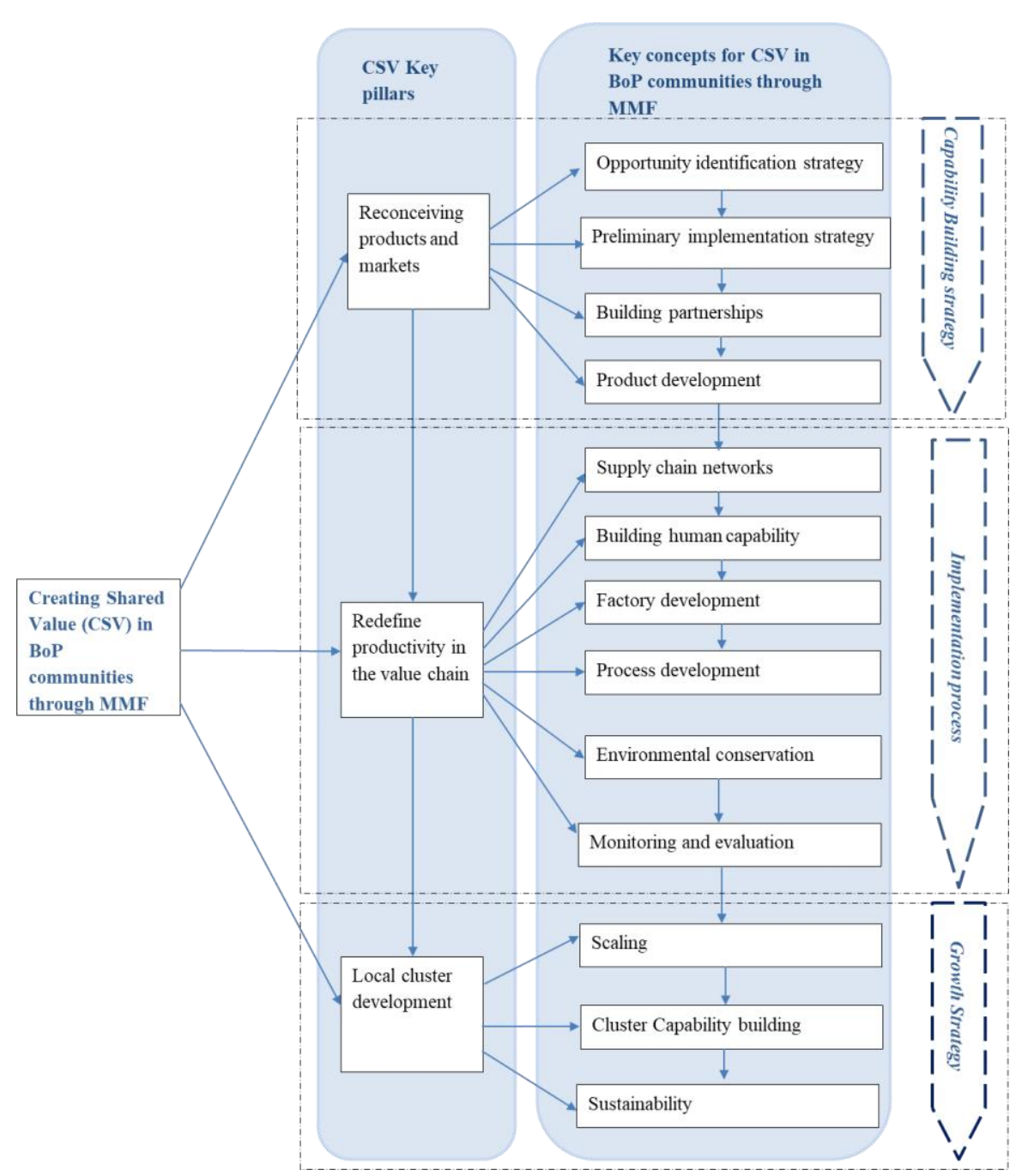

Fig. 8. Conceptual framework for Creating Shared Value in BoP communities through MMF

\section{$5 \quad$ Future work and limitations}

A systematized literature review can be used to meet various goals. This study sought to answer the research question on the key concepts that are to be considered for creating shared value in BoP communities with micro-manufacturing factories. These concepts were used to come up with a conceptual framework which will be evaluated and developed further in further studies. The evaluation process will be used to refine the conceptual framework to provide a roadmap for creating manufacturing shared value in BoP communities through micro-manufacturing factories. The review also assisted in identifying research gaps. 
The study is limited through its focus on BoP communities and manufacturing also a limited range of databases were searched for these articles. Future work may include expanding this study to grey literature. Future studies may expand the search terms to also explore other kinds of shared value beyond manufacturing and the Base of the Pyramid.

\section{Acknowledgements}

The authors would like to acknowledge support received from the Organization for Women in Science for the Developing World (OWSD), Sida (Swedish International Development Cooperation Agency) and the Schlumberger Foundation.

\section{References}

1. Albert, P. J., Werhane, P. and Rolph eds., T. (2014) Global Poverty Alleviation: A Case Book. doi: 10.1007/978-94-007-7479-7.

2. Angeli, F. and Jaiswal, A. K. (2015) 'Competitive Dynamics between MNCs and Domestic Companies at the Base of the Pyramid: An Institutional Perspective', Long Range Planning. Elsevier Ltd, 48(3), pp. 182-199. doi: 10.1016/j.lrp.2013.08.010.

3. Ansari, S., Munir, K. and Gregg, T. (2012) 'Impact at the "Bottom of the Pyramid": The role of social capital in capability development and community empowerment', Journal of Management Studies, 49(4), pp. 813-842. doi: 10.1111/j.14676486.2012.01042.x

4. Armstong, R. M. and Grobbelaar, S. . (2018) 'Toward the development of Sustainable Business Models for Social Enterprises', in SAIIE29 Proceedings, pp. 549-561.

5. Arnold, M. G. (2018) 'Inclusive value creation for sustainability of frugal innovations in the base of the pyramid low-income contexts', Journal of Contemporary Management, 15, pp. 218-244. Available at: https://journals.co.za/content/journal/10520/EJC-14b4bc8cf8.

6. Arora, S. and Romijn, H. (2012) 'The empty rhetoric of poverty reduction at the base of the pyramid', Organization, 19(July 2011), pp. 481-505. doi: $10.1177 / 1350508411414294$.

7. Azmat, F., Ferdous, A. S. and Couchman, P. (2015) 'Understanding the Dynamics Between Social Entrepreneurship and Inclusive Growth in Subsistence Marketplaces', Journal of Public Policy \& Marketing : JPP\&M, 34(2), p. 252. doi: 10.1509/jppm.14.150.

8. Biswas, A. K., Tortajada, C., Joshi, Y. K. and Gupta, A. (2014) Creating Shared Value: Impacts of Nestlé in Moga, India, Springer. Available at: http://www.springer.com/us/book/9783319014623.

9. Brix-asala, C., Hahn, R. and Seuring, S. (2016) 'Reverse logistics and informal valorisation at the Base of the Pyramid : A case study on sustainability synergies and trade-offs', European Management Journal. Elsevier Ltd, 34(4), pp. 414-423. doi: 10.1016/j.emj.2016.01.004.

10. Cañeque, F. and Hart, S. (2015) Base of the Pyramid 3.0: Sustainable development through innovation and entrepreneurship. New York: Greenleaf.

11. Carlson, E. and Koch, J. (2017) Building a successful social venture: A guide for social entrepreneurs. 
12. Chihambakwe, Z. J., Oosthuizen, G. A., Matope, S. and Uheida, E. H. (2019) 'A conceptual framework to create shared value in base of the pyramid communities with micro-containerised factories', Procedia Manufacturing. Elsevier B.V., 33, pp. 160-167. doi: 10.1016/j.promfg.2019.04.020.

13. Chopra, S. K. and Narayana, M. G. P. L. (2012) 'Meeting Bottom of the Pyramid (BOP) needs by engineering sustainable solutions', Proceedings of the 2012 IEEE Conference on Technology and Society in Asia, T and SA 2012. IEEE, pp. 1-6. doi: 10.1109/TSAsia.2012.6397980.

14. Dembek, K., Sivasubramaniam, N. and Chmielewski, D. A. (2019) 'A Systematic Review of the Bottom/Base of the Pyramid Literature: Cumulative Evidence and Future Directions', Journal of Business Ethics. Springer Netherlands, 0(0), p. 0. doi: 10.1007/s10551-019-04105-y.

15. Dembek, K. and York, J. (2020) 'Applying a Sustainable Business Model Lens to Mutual Value Creation With Base of the Pyramid Suppliers', Business and Society. doi: $10.1177 / 0007650320973450$.

16. Desa, G. and Koch, J. L. (2014) 'Scaling Social Impact : Building Sustainable Social Ventures at the Base-of-the-Pyramid', Journal of Social Entrepreneurship. Taylor \& Francis, 5(2), pp. 146-174. doi: 10.1080/19420676.2013.871325.

17. Filard, F., Barros, F. D. and Fischmann, A. A. (2018) 'Business strategies for the bottom of the pyramid: multiple case studies of large companies in the pacified communities of Rio de Janeiro', RAUSP Management Journal. Departamento de Administração, Faculdade de Economia, Administração e Contabilidade da Universidade de São Paulo - FEA/USP, 53(1), pp. 63-73. doi: 10.1016/j.rauspm.2017.12.003.

18. Fox, S. (2015) 'Moveable factories: How to enable sustainable widespread manufacturing by local people in regions without manufacturing skills and infrastructure', Technology in Society. Elsevier Ltd, 42, pp. 49-60. doi: 10.1016/j.techsoc.2015.03.003.

19. Gaertner, K. and Ishikawa, E. (2014) Shared Prosperity through Inclusive Business : How Successful Companies Reach the Base of the Pyramid, International Finance Corporation. doi: 10.1596/20594.

20. Gold, S., Hahn, R. and Seuring, S. (2013) 'Sustainable supply chain management in "Base of the Pyramid" food projects-A path to triple bottom line approaches for multinationals?', International Business Review, 22(5), pp. 784-799. doi: 10.1016/j.ibusrev.2012.12.006.

21. Goldsmith, A. A. (2011) 'Profits and Alms: Cross-sector partnerships for Global Poverty Reduction', Public Administration and Development, 31, pp. 15-24. doi: $10.1002 / \mathrm{pad}$.

22. Grant, M. J. and Booth, A. (2009) 'A typology of reviews: An analysis of 14 review types and associated methodologies', Health Information and Libraries Journal, 26(2), pp. 91-108. doi: 10.1111/j.1471-1842.2009.00848.x.

23. Hahn, R. and Gold, S. (2014) 'Resources and governance in "base of the pyramid"partnerships: Assessing collaborations between businesses and non-business actors', Journal of Business Research. Elsevier Inc., 67(7), pp. 1321-1333. doi: 10.1016/j.jbusres.2013.09.002.

24. Holt, D. and Littlewood, D. (2014) 'Informal economy entrepreneurs from subSaharan Africa Observations from Kenya', in Routledge Companion to Business in Africa. Routledge 978-0-415- 63545-5, pp. 198-217.

25. Hossain, M. (2021) 'Frugal innovation and sustainable business models', Technology in Society. doi: 10.1016/j.techsoc.2020.101508.

26. Jacob, S. and Pin, K. (2011) 'Improving Lives in the Base of Pyramid, Profitably', Social Space, pp. 48-53. Available at: https://ink.library.smu.edu.sg/lien_research/82. 
27. Jäger, U., Symmes, F. and Cardoza, G. (2020) Scaling Strategies for Social Entrepreneurs A amrket approach, Springer Nature 2020. Palgrave Macmillan. doi: 10.1007/978-3-030-31160-5.

28. Jenkins, B. (2007) Expanding Economic Opportunity: The Role of Large Firms. Corporate Social Responsibility Initiative Report No. 17.

29. Karnani, A. (2007) 'Fortune at the Bottom of the Pyramid: A Mirage How the private sector can help alleviate poverty', Business, (1035), p. 40.

30. Karnani, A. (2011) Fighting Poverty Together: Rethinking Strategies for Business, Governments, and Civil Society to Reduce Poverty, Palgrave Macmillan. doi: $10.1057 / 9780230120235$

31. Kasturi Rangan, V., Chu, M. and Petkoski, D. (2011) 'The globe: Segmenting the base of the pyramid', Harvard Business Review, 89(6), pp. 3-8.

32. Knuckles, J. (2016) 'Business models for mini-grid electricity in base of the pyramid markets', Energy for Sustainable Development. International Energy Initiative, 31, pp. 67-82. doi: 10.1016/j.esd.2015.12.002.

33. Lashitew, A. A., Bals, L. and van Tulder, R. (2018) 'Inclusive Business at the Base of the Pyramid: The Role of Embeddedness for Enabling Social Innovations', Journal of Business Ethics, 162(July), pp. 421-448. doi: 10.1007/s10551-018-3995-y.

34. Leke, A., Chironga, M. and Desvaux, G. (2018) Africa's Business Revolution: How to Succeed in the World's Next Big Growth Market. Harvard Business Review Press. Available at: https://web.a.ebscohost.com/ehost/ebookviewer/ebook/ZTA3NnR3d19fMTc5Nzg2N V9fQU41?nobk=y\&sid=9e21e2fd-652a-41bb-936a-c821ad8c0e59@sdc-vsessmgr01\&vid=12\&format $=\mathrm{EB} \&$ rid $=1$.

35. London, T., Anupindi, R. and Sheth, S. (2010) 'Creating mutual value: Lessons learned from ventures serving base of the pyramid producers', Journal of Business Research. Elsevier Inc., 63(6), pp. 582-594. doi: 10.1016/j.jbusres.2009.04.025.

36. London, T., Sheth, S. and Hart, S. (2014) A Roadmap for the Base of the Pyramid Domain: Re-energizing for the Next Decade, William Davidson Institute at the University of Michigan.

37. London, T. (2020) The Base of the Pyramid Promise. Redwood City: Stanford University Press. doi: https://doi.org/10.1515/9780804797337.

38. Madyira, D. M. (2016) 'Development of container based community factories', in 7 th International conference on Aproppriate Technology, Victoria falls, Zimbabwe.

39. Marconatto, D. A. B., Barin-Cruz, L., Pozzebon, M. and Poitras, J. E. (2016) 'Developing sustainable business models within BOP contexts: Mobilizing native capability to cope with government programs', Journal of Cleaner Production. Elsevier Ltd, 129, pp. 735-748. doi: 10.1016/j.jclepro.2016.03.038.

40. Van Der Merwe, M. D., Grobbelaar, S. S., Schutte, C. S. L. and Von Leipzig, K. H. (2018) 'Toward an Enterprise Growth Framework for Entering the Base of the Pyramid Market: A Systematic Review', International Journal of Innovation and Technology Management. doi: 10.1142/S0219877018500359.

41. Moellmann, J. and Thomas, V. M. (2019) 'Social enterprise factory location and allocation model: Small scale manufacturing for East Africa', Socio-Economic Planning Sciences. Elsevier, 68(February), p. 100694. doi: 10.1016/j.seps.2019.02.009.

42. Moher, D., Liberati, A., Tetzlaff, J. and Altman, D. G. (2009) 'Preferred reporting items for systematic reviews and meta-analyses: The PRISMA statement', $B M J$ (Online), 339(7716), pp. 332-336. doi: 10.1136/bmj.b2535.

43. Nittapaipapon, N. and Atchattabhan, T. (2016) 'Creating Shared Value Embedded an Inclusive Business Model : A Case Study', Asian Journal of Business and Management, 04(02), pp. 56-64. 
44. Okpara, J. O. and Wynn, P. (2007) 'Determinants of small business growth constraints in Sub-Saharan African Economy', S.A.M. Advanced Management, 72(2), pp. 24-35.

45. Panapanaan, V., Bruce, T., Virkki-Hatakka, T. and Linnanen, L. (2016) 'Analysis of Shared and Sustainable Value Creation of Companies Providing Energy Solutions at the Base of the Pyramid (BoP)', Business Strategy and the Environment, 25(5), pp. 293-309. doi: 10.1002/bse.1866.

46. Peerally, J. A., De Fuentes, C. and Figueiredo, P. N. (2019) 'Inclusive innovation and the role of technological capability-building: The social business Grameen Danone Foods Limited in Bangladesh', Long Range Planning. Elsevier, 52(6), p. 101843. doi: 10.1016/j.lrp.2018.04.005.

47. Plambeck, E. L. and Ramdas, K. (2020) 'Alleviating poverty by empowering women through business model innovation: Manufacturing \& service operations management insights and opportunities', Manufacturing and Service Operations Management, 22(1), pp. 123-134. doi: 10.1287/msom.2019.0844.

48. Porter, M. E. and Kramer, M. R. (2011) 'Creating shared value', Harvard Business Review, 89(1-2). doi: 10.1108/09600039410055963.

49. Prahalad, C. K. (2005) The Fortune at the Bottom of the Pyramid: Eradicating Poverty Through Profits. Enabling Dignity and Choice Through Markets.

50. Prahalad, C. K. (2009) The fortune at the bottom of the pyramid, revised and updated 5th anniversary edition: Eradicating poverty through profits. FT Press.

51. Prahalad, C. K. (2012) 'Bottom of the Pyramid as a Source of Breakthrough Innovations', Journal of Product Innovation Management, 29(1), pp. 6-12.

52. Prahalad, C. K. and Hammond, A. (2002) 'Serving the world's poor, profitably', Harvard Business Review, 80(9), p. 48. doi: 10.1108/02756660710732611.

53. Prasad, S., Jaffe, J., Bhattacharyya, K., Jasmine, T. and Marshall, D. (2017) 'Value supply chains at the base of the pyramid: studies of past and present textile networks', Journal of Humanitarian Logistics and Supply Chain Management, 7(3), pp. 304323.

54. Rahdari, A., Sepasi, S. and Moradi, M. (2016) 'Achieving sustainability through Schumpeterian social entrepreneurship : The role of social enterprises', Journal of Cleaner Production. Elsevier Ltd, 137, pp. 347-360. doi: 10.1016/j.jclepro.2016.06.159.

55. Reiner, G., Gold, S. and Hahn, R. (2015) 'Wealth and health at the Base of the Pyramid: Modelling trade-offs and complementarities for fast moving dairy product case', International Journal of Production Economics, 170(August), pp. 413-421. doi: 10.1016/j.ijpe.2015.08.002.

56. Rethlefsen, M., Kirtley, S., et al. (2021) 'PRISMA-S: An Extension to the PRISMA Statement for Reporting Literature Searches in Systematic Reviews'. Systematic Reviews, pp. 1-19. doi: 10.31219/osf.io/sfc38.

57. Rodrigues, J. and Baker, G. A. (2012) 'Grameen danone foods limited (GDF)', International Food and Agribusiness Management Review, 15(1), pp. 127-158.

58. Schleinkofer, U., Dazer, M., et al. (2019) 'Framework for robust design and reliability methods to develop frugal manufacturing systems', Procedia CIRP. Elsevier B.V., 81, pp. 518-523. doi: 10.1016/j.procir.2019.03.148.

59. Schuster, T. and Holtbrügge, D. (2014) 'Benefits of Cross-sector Partnerships in Markets at the Base of the Pyramid', Business Strategy and the Environment, 23(3), pp. 188-203. doi: 10.1002/bse.1780.

60. Siebold, N., Günzel-Jensen, F. and Müller, S. (2019) 'Balancing dual missions for social venture growth: a comparative case study', Entrepreneurship and Regional Development, 31(9-10), pp. 710-734. doi: 10.1080/08985626.2018.1554710.

61. Simanis, E. and Hart, S. (2008) 'The Base of the Pyramid Protocol: Toward Next 
Generation BoP Strategy', Innovations: Technology, Governance, Globalization, 3(1), pp. 57-84. doi: 10.1162/itgg.2008.3.1.57.

62. Sinkovics, N., Sinkovics, R. R. and Yamin, M. (2014) 'The role of social value creation in business model formulation at the bottom of the pyramid - Implications for MNEs?', International Business Review. Elsevier Ltd, 23(4), pp. 692-707. doi: 10.1016/j.ibusrev.2013.12.004.

63. Slepov, D. (2016) Micromanufacturing the future, Techcrunch. Available at: https://techcrunch.com/2016/04/03/micromanufacturing-the-future/?guccounter=1.

64. Spitzeck, H. and Chapman, S. (2012a) 'Creating shared value as a differentiation strategy - the example of BASF in Brazil', Corporate Governance (Bingley), 12(4), pp. 499-513. doi: 10.1108/14720701211267838.

65. Spitzeck, H. and Chapman, S. (2012b) 'Creating shared value as a differentiation strategy - the example of BASF in Brazil', Corporate Governance, 12(4), pp. 499513. doi: http://dx.doi.org.ezp.waldenulibrary.org/10.1108/14720701211267838.

66. Tashman, P. and Marano, V. (2010) 'Dynamic capabilities and base of the pyramid business strategies', Journal of Business Ethics, 89(SUPPL. 4), pp. 495-514. doi: 10.1007/s10551-010-0403-7.

67. Ueda, K., Takenaka, T., Váncza, J. and Monostori, L. (2009) 'Value creation and decision-making in sustainable society', CIRP Annals - Manufacturing Technology, 58(2), pp. 681-700. doi: 10.1016/j.cirp.2009.09.010.

68. Varadarajan, R. and Kaul, R. (2018) 'Doing well by doing good innovations: alleviation of social problems in emerging markets through corporate social innovations', Journal of Business Research. Elsevier Inc., 86, pp. 225-233. doi: 10.1016/j.jbusres.2017.03.017

69. Varga, V. and Rosca, E. (2019) 'Driving impact through base of the pyramid distribution models: The role of intermediary organizations', International Journal of Physical Distribution and Logistics Management, 49(5), pp. 492-513. doi: 10.1108/IJPDLM-01-2018-0040. 